\title{
Die Logik
}

als

\section{Wissensehafts lehre}

dargestellt

voll

\section{Dr. Leopold George,}

ordentlichem Professor der Philosophie an der Universität zu Greifstrald.

\section{Berlin,}

Druck und Verlag von Georg Reimer.

1868. 



\title{
Den Manen
}

seines verklärten Lehrers

\section{Friedrich Schleiermacher}

\author{
zu seinem hundertsten Geburtstage
}

in tiefster Verehrung und Dankbarkeit

gewidmet

rom

Verfasser. 
